\title{
Extracurricular Activities of Students as An Object of Project Management in A Comprehensive School
}

\author{
Elena Zemlyanskaya ${ }^{1^{*}}$ \\ ${ }^{1}$ Moscow Pedagogical State University, Theory and Practice of Primary Education Department, \\ Moscow, Russia
}

\begin{abstract}
The purpose of the study is to reveal the essence of extracurricular activities of students within the federal state standards as an object of project management in an educational organization of general education. The place of extracurricular activities is determined as a full and compulsory component of the main educational program. The essence of extracurricular activities, its relationship with the planned educational results, as well as the difference from continuing education, are revealed. The results of the study of educational programs and examples of the design of plans of extracurricular activities by the teaching teams of schools are presented. The algorithm for designing a plan for extracurricular activities is described. The initial, conceptual and design stages are highlighted and characterized. The scientific novelty consists in substantiating the content of the concept of extracurricular activities of a school, including the presentation system on goals, design strategies, principles for selecting content, formats and implementation procedures.
\end{abstract}

\section{Introduction}

The basis of modernization changes to improve the quality of educational programs is the idea of making learning an active process in which students have the opportunity to construct their knowledge in connection with their previous educational experience and using the capabilities of the educational environment $[1,2]$. This leads to the fact that education in a modern school goes beyond the scope of subjects. As a result, an idea came up when designing and implementing educational programs to use the potential of added educational practices, which are represented in extracurricular activities and additional education in a Russian school.

One of the ways to implement this idea was the introduction in 2011 in the educational standard of the provision that the main educational program (MEP) of the school is implemented through the organization of lesson and extracurricular activities, which is considered as an obligatory part of the educational program of the school. The significance of extracurricular activities is to eliminate the subject disunity of the content and pressure of the classroom organization [3].

* Corresponding author: en.zemlyanskaya@mpgu.su 
When designing an educational program, the planned educational results, as well as, to a certain extent, the content of education and its results are "distributed" between lesson and extracurricular activities, taking into account the specific forms of organization of students' activities. In other words, the system of extracurricular activities of a school allows enriching the content of education and technology of a holistic educational program. It allows using accessible from the didactic point of view, new objects of human activity, which, in turn, allows students to develop new "ideal activities" [4].

Extracurricular activities, entering the educational program of a school and becoming its full-fledged component ensures the achievement of the planned educational results. Extracurricular activities are carried out through the implementation of work programs developed in accordance with the educational standard [3]. This is its difference from supplementary education, which not being mandatory and planned in its semantics "supplements" education [5].

In foreign education, the concept of nonformal education is used. P. Coombs and M. Ahmed attributed to it any organized educational activity outside formal education and identified it as a separate activity aimed at serving subjects of learning and realizing personal learning goals [6].

E. S. Babaeva summarized the international experience of nonformal education and determined its subjective characteristics: orientation on the educational needs of specific categories of students; mobility and a high level of student activity; flexibility in the organization and teaching methods, etc. [7].

Studies emphasize the importance of nonformal education to help students with special educational needs to master educational programs $[8,9]$.

Discussion of the effectiveness of nonformal educational programs $[10,11]$ proves that nonformal education can significantly help in mastering the basic educational program when it is designed in combination with a formal curriculum. This point of view is supported by I. A. Ardabatskaia: nonformal education can be perceived not only as additional, but also as inseparable from the formal school [12].

The mechanisms of the development of education are in the transition to a strategy for constructing the learning process, ensuring the achievement of a qualitative resu 1 of the development of the personality of students [3]. The realization of the potential of extracurricular activities is possible only with the subjective participation of teachers in the procedures for its design as a component of the holistic educational program of a school.

According to Gabriele and Joram [13], reform-based education requires faith in the effectiveness of one's own actions and the expectation of success from their implementation [13]. An educational project is always a product of the work of a project team of educators. Schmoker (2005) stated that the right kind of continuous, structured collaboration between teachers improves the quality of teaching and brings great, often immediate, dividends in student learning and professional growth in almost any environment.

Susan Colby, Monica Lambert, Jennifer McGee disclose strategies for how collaborative analysis and design were used in their college's practice to improve the program [14], justifying the need to create so-called professional teacher communities that build the collective potential of stakeholders to improve practice and become the norm in modern schools. DuFour and Eaker (1998) argue that the creation of such communities is "the most promising strategy for sustainable, significant improvement of the school" $[15,16]$. Other scientists agree that the work of project teams is a promising technique for improving practice and raising the level of student learning $[17,18]$.

According to the stated purpose, the study solves the following tasks:

1. To emphasize the psychological and pedagogical essence of the category of extracurricular activities. 
2. To analyze the place of extracurricular activities in the educational programs of schools and the examples of its design.

\section{Methods}

To solve problem 1, the constructive genetic method was used to identify the essence of extracurricular activities, and the analysis of psychological and pedagogical publications on the problems of additional and nonformal education was carried out.

To solve problem 2, in 2017-2019 an empirical study was organized with the participation of undergraduates from pedagogical universities in Moscow. The documentation of 194 elementary schools was studied. Two hundred and eighty-four primary school teachers in Russian schools participated in surveys and interviews. Methods used: analysis of educational programs of schools; survey of participants in the educational process of a school; analysis of precedents of the development of modules and systems of extracurricular activities.

In the process of analyzing the MEP, the following components were studied: plan of extracurricular activities, target section, and the program for the formation of universal educational actions for students. The analysis was carried out according to the following criteria: the adequacy of the plan of extracurricular activities for the student population; coherence of the plan of extracurricular activities and the program for the formation of universal educational actions for students; the presence of sound algorithms and procedures for students to choose after-school activities in the plan.

The survey of teachers revealed the degree of their participation in the design of educational programs; understanding of the nature, role and place of extracurricular activities in the educational process; the desire of teachers to agree on extracurricular activities and curriculum programs; using the potential of extracurricular activities to meet the special educational needs of a child.

When analyzing the analysis of the examples of designing plans for extracurricular activities by the teaching teams of schools, we considered it as a consciously constructed, meaningful and framed fragment of professional activity. Examples were identified based on conversations with school principals and teachers and were justified by project developments. The criteria for assigning a narrative to an example were: uniqueness (specificity, dissimilarity), design (highlighting significant relationships and hierarchical relationships); the naturalness of the basic pedagogical and life processes of the educational organization.

\section{Results}

It has been established that the plan of extracurricular activities does not sufficiently reflect the conceptual orientation of the school's educational program; several plans do not take into account the characteristics of the student population, as well as the specifics of microsocium in the school district, etc. The analysis of the plans for extracurricular activities confirmed our suspicion of unsystematic and eclectic nature in the selection of extracurricular activities; lack of well-thought-out procedures for students to choose extracurricular activities and their sequence. The modular structure of the plan of extracurricular activities and the modular construction of extracurricular activities programs, are almost never encountered.

Table 1. Elementary school teacher survey results (\%)

Parameters

\begin{tabular}{|c|c|}
\hline \multicolumn{2}{|c|}{$\begin{array}{l}\text { Teachers are involved in } \\
\text { the design of MEP }\end{array}$} \\
\hline Yes & $\mathrm{No}$ \\
\hline
\end{tabular}




\begin{tabular}{|l|l|l|}
\hline $\begin{array}{l}\text { Can explain the difference between the concepts of extracurricular } \\
\text { activities and continuing education }\end{array}$ & 94 & 28 \\
\hline Implement extracurricular activities & 90 & 62 \\
\hline Coordinate thematic lesson planning with extracurricular activities & 86 & 32 \\
\hline $\begin{array}{l}\text { Extracurricular activities are used to meet the special educational needs } \\
\text { of a child and to build individual educational routes }\end{array}$ & 86 & 28 \\
\hline Advise parents on choosing extracurricular activities & 86 & 70 \\
\hline
\end{tabular}

\section{Discussion}

Extracurricular activities are an opportunity to improve educational programs and innovative development of a school. In the mass pedagogical and everyday consciousness, there is unity or the indivisibility of concepts: extracurricular activities and additional education, extracurricular or after-school work. We can state a contradiction between the increase in the importance of school activities in the structure of the MEP and the underestimation of its potential by the project teams of educational programs. The correlation was revealed between the teacher's participation in the project team and their understanding of the essence of the phenomenon of extracurricular activities.

The results of the study revealed the specifics of the technology for designing extracurricular activities. The product of the project activity of the school team is the plan of extracurricular activities, understood as a sequence of actions united by a common goal and intended to be carried out in the process of implementing an educational program.

The project work algorithm includes the following steps: development of a project concept; project planning; project implementation; project presentation; evaluation and reflection of the project.

We pay special attention to the conceptual phase of a project, the purpose of which is seen in: developing the concept; modeling; diagnostics of reality and the formation of values, meanings, and goals.

The concept of the plan of extracurricular activities is developed based on a situation analysis and awareness or forecasting of social needs. From the psychological and pedagogical point of view at the conceptual stage of a project, it is important for each participant to discover and experience the prospect of possible participation and to make sure that they are able to improve pedagogical reality by their own efforts. Using standardized methods of forecasting (Foresight, mapping, SWOT-analysis, etc.) allows to optimize the stage, the result of which is a formulated idea of the goals of extracurricular activities, design strategies, and principles of selection of content, which together determine the model of extracurricular activities of a school.

The design strategies for the plan of extracurricular activities are determined by the weight fractions of the types of pedagogical design:

psychological and pedagogical design (extracurricular activities set the developing educational conditions for the formation of human subjectivity: implementing a differentiated approach based on age-normative development models and age-appropriate pedagogical activity, taking into account individual characteristics and needs of the contingent);

sociopedagogical design (in which extracurricular activities are designed as an institution or educational environment that is adequate to the needs of families, cultural traditions, national and ethnocultural characteristics of the region; provides for the use of the potential and characteristics of society, ensuring the network interaction of social institutions; focused on solving socially significant problems of the settlement);

pedagogical design, in which extracurricular activities are considered as educational practices, technologies and means of pedagogical activity. 
The principles of content filling the plan and programs of extracurricular activities of the school are determined by leading pedagogical approaches and allow us to conceptualize the results of extracurricular activities in a holistic educational program. They are the basis of the model of the plan of extracurricular activities, which includes several aspects: logical and substantive; logical subject; logical-object (objects of reality included in the study); objectoperational (pedagogical technologies, methods of activity).

\section{Conclusion}

Extracurricular activities are a full and compulsory component of the MEP. In contrast to additional education, it, along with the lesson activities, is focused on the achievement of the planned educational results by the students. The plan of extracurricular activities is one of the organizational mechanisms for the implementation of MEP; it is designed along with other components of a holistic MEP. Conceptualization is a necessary stage in the development of a plan. The concept includes: a description and semantic assessment of the formulated based on the sociological, logical and psychological analysis of the problematic field of a project; valuable grounds and goals of a project; theoretical approaches, strategies and design principles; description of a project format (for example, the modular structure of a plan); procedures for implementing a plan and building individualized educational trajectories.

In the field of methodology and organization of extracurricular activities in general education, new pedagogical research should be expected. For example, the problem of the relationship of the system of extracurricular activities with the level of educational achievements of students (subject, personality or metasubject), its focus on the formation of key competencies of students modularization of the extracurricular activities plan and its programs; networking in the organization of extracurricular activities; development of a methodology for goal setting and designing the content of education in a single system of a lesson and extracurricular activities.

\section{References}

1. Ye.N. Zemlyanskaya, Shkola budushchego 6, 10-19 (2016)

2. R. Millar, R. Driver, Studies in Science Education 14, 33-62 (1987)

3. Federal State Educational Standard for Elementary General Education (as amended on May 18, 2015, as well as as amended by Order of the Ministry of Education of Russia dated 12.31.2015 No. 1576).

4. Ye.N. Zemlyanskaya, M.Ya. Sitnichenko, Nauka i shkola 5, 12-17 (2013)

5. Letter of the Ministry of Education of Russia No. 03-PG-MP-42216 "On the participation of students of municipal and state schools of the Russian Federation in extracurricular activities", 5 September (2018)

6. P. Coombs, M. Ahmed, Attacking Rural Poverty. How non-formal education can help (John Hopkins Press, Baltimore, 1974)

7. E.S. Babayeva, Gumanizatsiya obrazovaniya 2, (2015)

8. D. Colardyn, J. Bjornavold, European Journal of Education 39, 70-89 (2004)

9. S. Nath, N. Sylvia, J. Grimes, International Review of Education 45, 5-26 (1999)

10. D. Huffman, F. Lawrenz, K. Thomas, American Journal of Evaluation 29, 358-368, (2008)

11. J. Walahoski, L. Suzanne,Journal on Youth Development 7 77-81, (2012) 
12. I.A. Ardabatskaya, Vestnik Kostromskogo gosudarstvennogo universiteta. Seriya: Pedagogika. Psikhologiya. Sotsiokinetika 1, (2016)

13. A.J. Gabriele, E. Joram, Action in Teacher Education 29, 60-74 (2007)

14. S. Colby, M. Lambert, J. McGee, SAGE Open 6(4), 1-12 (2016)

15. R. DuFour, Educational Leadership 73(3), 22-26 (2015)

16. R. DuFour, R. E. Eaker. Professional learning communities at work: Best practices for enhancing student achievement (National Education Service, Bloomington, 1998)

17. J. Mitchell, International Journal of Adult, Community and Professional Learning 21(1), $1-13$ (2014)

18. M. Ronfeldt, S.O. Farmer, K. McQueen \& J.A. Grissom, American Educational Research Journal 52, 475-514 (2015)

19. M. Schmoker, Here and now: Improving teaching and learning, In R. Dufour, R. Eaker, \& R. Dufour (Eds.). On common ground: The power of professional learning communities (Solution Tree Press, Bloomington, 2005) 